\title{
Tricksterism and Humor in Bread Givers (1925) by Anzia Yeziaska $^{i}$
}

\author{
Zhou Jingqiong \\ Faculty of English Language and Culture, Guangdong University of Foreign Studies, People's Republic of China
}

Copyright $(2017$ by authors, all rights reserved. Authors agree that this article remains permanently open access under the terms of the Creative Commons Attribution License 4.0 International License

\begin{abstract}
This paper deals with the trickster narrative and humorous characterization in Bread Givers (Anzia Yezierska, 1925). It starts first with characteristics typical of tricksterism, which is divided into two parts, trickster narrative and humorous characterization. Then the social and cultural circumstances are introduced of the early $20^{\text {th }}$-century decades where Anzia Yezierska stood out as a unique Jewish writer with her masterpiece, Bread Givers. The trickster narrative of the female protagonist is explored, followed by the humorous characterization of Reb Smolinsky, her father. To conclude, tricksterism and humor serve their thematic and moral functions in the novel: they help the characters tide over poverty, sexism, and racism, and ultimately enable Sara, the narrator protagonist to rise from ghetto to a middle class career.
\end{abstract}

Keywords Trickster Narrative, Humorous
Characterization, Modernity, Bread Givers

\section{Characteristics That Most Tricksters Share}

Trickster strategies such as masking have always been an integral part of American culture. Masking is "in the American grain. America is a land of masking jokers. We wear the mask for purposes of aggression as well as for defense; when we are projecting the future and preserving the past" (Ellison [6], 55). It was not until the appearance of Paul Rodin's 1956 study The Trickster that tricksters began to be considered cross-cultural phenomena. Since the early 1990s, studies into play, humor, and laughter have made their way into the study of trickster characters. Such characters appear prominently in $20^{\text {th }}$ century American novels by writers of color. Trickster protagonists and tricksterlike narrative forms are their common ground.

Victor Turner [14] calls tricksters "liminal phenomena" and maintains that their wide presence in world literatures derives from their liminality, the "betwixt and between state of transition and change that is a source of myth in all cultures" (580). Tricksters dwell at crossroads and thresholds and are endlessly multifaceted and ambiguous. Tricksters are uninhibited by social constraints. Perpetual wanderers, tricksters can escape virtually any situation, and they possess a boundless ability to survive. It is these last two qualities that make the trickster not simply a figure to laugh at but also a hero. Huck Finn is a good case in point (Christen [5], 77-78).

Despite their apparent marginality and irreverence, trickster tales teach through comic examples and define culture by transgressing its boundaries. Trickster's challenge to established order shows the limits of any social or political system, thus preparing the way for creative change and adaptation.

\section{Ideology vs. Trickster Narrative}

Smith's [13] "trickster aesthetic envisions the trickster not only as an actual figure in the novel but also as a linguistic and stylistic principle" (14). Two other recent studies of the trickster have also isolated the rhetorical as its principal terrain and clarified the connection between narrative form and ideological context. Henry Louis Gates, Jr. [9] declares that the signifying monkey's power and identity lie in his mastery of verbal technique: "The monkey is not only a master of technique, he $i$ s technique" (54). Gerald Vizenor [15] similarly emphasizes the Native American trickster's relationship to form and style, translating the trickster's characteristics into features of language that make up what he calls "trickster discourse." In his view, the trickster is "disembodied in a narrative... a communal sign, a comic holotrope and a discourse" (196).

Sara Smolinsky, narrator and protagonist of Bread Givers, fits into plentiful aforesaid descriptions assigned to the trickster character. A second-generation immigrant, she is experiencing a social and cultural transition from a Russian Jew to an American Jew. Stuck at cultural and physical crossroads-between the slum of Hester Street and the modern outside world - before she reaches her teens, she refuses to be inhibited by social constraints and succeeds in 
shaking off the economic and psychological stigmas that condemn female ethnic immigrants to the bottom of the social hierarchy. To realize her American dream, she moves from city to city, to work as a cheap laborer in sweat shops while attending night school. Then she moves to a new city to attend college and becomes a grammar school teacher later. With the help of tricksterism, she finally finishes her transformation from a poverty-stricken immigrant girl locked in the slum of Hester Street to a school teacher, a member of the middle class.

\section{Social and Cultural Circumstances That Produced Jewish Literature}

A brief look is in place at the social and cultural circumstances under which Anzia Yezierska, the novelist published her novel.

The greatest scope of immigration to the US occurred in two waves: the "old immigration" of 1820 to 1860 , consisted mainly of Northwestern Europeans including the British, Irish, and the Germans. The new immigration that appeared from 1870 to 1913 included many of British and German descent, and increasingly large percentages of East and South Europe-Russian-Polish Jews, Austrian and Rumanian Jews, Catholic Poles, Italians, etc.

By the 1910s, the US had transformed from a British-dominated country into a poly-ethnic and increasingly urban nation. Modernization in full swing, American society was slowly shifting from a rural producer economy that stressed work and thrift to an urban consumer economy where personal identity was constructed in close association with new forms of entertainment, leisure activities, and material possessions. Many middle-class Americans now enjoyed unheard-of levels of comfort and convenience. Class divisions were sharpened.

While the middle and upper classes prospered immigrants, farmers, and the urban working classes - the overwhelming majority of the population-improved their families' economic position only slowly and slightly.

The majority of immigrants settled in cities in the northeastern and north-central states. For many immigrants, the stress of adjusting to a new life was eased by settling among compatriots who had arrived earlier. Hester Street in East Side, Manhattan, for example, is the place for immigrant Jews.

Meanwhile, racism ran rampant: fearing the loss of the privileges and status associated with their white skin color, native-born whites often stereotyped immigrants as racially different and inferior. Only gradually, and with much effort, did Irish, Jews, Slavs, and Italians come to be considered "white." Every major city had its share of slums and then ghettos, when laws, prejudice, and community pressure prevented the tenement inhabitants from renting elsewhere. Hester Street is a good illustration, where immigrant Jews lived locked in segregated ghettos.

In the 1910s and 1920s, American national concern began to shift from life among the masses of foreign population to whether or not they could or would "assimilate." In 1895, Abraham Cahan, a labor organizer and co-founding editor of the Jewish Daily Forward, published Yekl: A Tale of the New York Ghetto. In 1974, Hester Street, a film based on Yekl, was made. Cahan was actually best known for his novel The Rise of Levinsky (1917). With realistic detail, Cahan tells how Levinsky, a former Jewish student, becomes a major garment-manufacturer worth millions: not only through hard work and ingenuity but also through cynical manipulation of his workers and their faith. "Undermining the Shylock stereotype, Cahan attributes Lewinsky's entrepreneurial energy not to blood but to the internalization of mainstream American values.... In 1922, the novel was proclaimed the most important of all immigrant novels" (Ferraro [8], 386).

\section{Introduction of Anzia Yezierska and Bread Givers}

Cahan's literary achievements paved the way for the arrival of Anzia Yezierska on the American literary scene. She published between 1920 and 1932 two collections of short stories and four novels about the trials of Russian Jewish immigrants fighting the economic and social restrictions of the East Side, Manhattan. Bread Givers looks back at East Side mobility through a feminism that may have been self-referential - in the mid-1910s, Yezierska left her husband and daughter for rooms of her own.

Public interest attached itself less to Yezierska's books than to the figure of the author. When a producer purchased two of Yezierska's books for filming, Yezierska was turned into a Sunday Supplement celebrity through the mid-1920s, the decade when she became a household name just like F. Scott Fitzgerald, author of The Great Gatsby (1925).

Despite the fact that W. H. Auden wrote an introduction for her autobiography, Red Ribbon on a White Horse (1950), Yezierska's books were invisible from mid-century until the mid-1970s when Alice Kessler-Harris edited four volumes for republication, including Bread Givers, arguing for their importance as documents of the immigration of working women.

A brief summary of the plotline is in place.

Bread Givers is composed of three books. Book I, entitled "Hester Street," deals with the lives of the first generation Jewish immigrants in Hester Street situated in the Lower East Side of the New York City borough Manhattan.

This section narrates three events as stepping stones in Sara Smolinsky's coming of age as the youngest of the four girls in the Smolinsky household. First, her father is tried and acquitted for assaulting his landlord's collection agent, becoming a local hero whose reputation promotes the family boardinghouse. Second, Smolinsky interdicts the love affairs of his three elder daughters, arranges marriages for two of them through traditional matchmaking, and then brokers the marriage of his 
third daughter himself. Finally, he purchases a suburban grocery store, only to discover that he has been swindled.... The three events of "Hester Street" chronicle the family's modest progress from poverty to varying forms of security. (Ferraro [7], 60)

Book II, entitled "Between Two Worlds," embraces Sara's struggle for and success in obtaining an independent identity, starting with the story entitled "Shut the Door," where Sara combines sweat factory work with night school study in New York, her first step toward economic and intellectual independence. Then Sara, exposed to the epiphany of "Knowledge was what I wanted more than anything else in the world," moves to the Midwest to attend college, where, on Commencement day, she wins the essay contest with the apt topic: "What the College Has Done for Me."

Book III concludes with Sara's return to New York City and her rise from rags to material comfort and intellectual riches, so to speak, and her compromise with her old-fashioned patriarchal father. Toward the end of the novel, Sara reminds the reader of her appropriation of Standard English by criticizing the immigrant English of her elementary-school pupils. She notes, "My children used to murder the language as I did when I was a child of Hester Street. And I wanted to give them that better speech that the teachers in college had tried to knock into me" (Yezierska [16], 271).

\section{The Trickster Narrative of Bread Givers}

"The starting position of the trickster in literary and cinematic narratives is always that of imprisonment, constraint and limitation" (Bassil-Morozow [2], 24). Sara, narrator and protagonist of Bread Givers is no exception.

Cicero examines, in On the Orator, the techniques of humor in public speaking and contributes an essential division of humor: "There are two kinds of jokes, one of which is based on things, the other on words" (qtd. in Morreall [11], 17). In line with Cicero, Bergson [3] draws a distinction between the humor expressed and the humor created by language (33). Such a division provides an accessible way to analyze humor in terms of what is being talked about and the humor arising from the language itself, namely, narrative humor.

As regards the devices for narrative humor, different critics have resorted to different tool kits.

Sara Smolinsky, the narrator protagonist, is a second-generation immigrant girl and has to struggle fiercely with her poverty-stricken immigrant status. Exaggeration is typical of her narrative of the life of her immigrant family. In the opening chapter of the novel, Sara is ten years old. She has three older sisters, Bessie, Mashah and Fania, all of them unemployed as the story begins. Bessie, the eldest sister upon whose neck the whole family is hanging for her wages, returns home from another fruitless search for work as Sara is peeling potatoes for the family's supper. Here is what appears in Sara's imagination as a consequence of Bessie's continuous unemployment:

I already saw all our things kicked out on the sidewalk like a pile of junk. A plate of pennies like a beggar's hand reaches out of our bunch of rags. Each sigh of pity from the passers-by, each penny thrown into the plate was another stab into our burning shame. (Yezierska [16], 2)

Unemployment adds fuel to fire in this immigrant family living in the slum of Hester Street. But the narrative, brimmed with humor as a result of exaggeration, gives the impression that something like a carnival is intended out of this imaginary scene of expulsion from the landlord, thus inserting some sense of warmth, if not so much as a light of hope, into the narrative.

Mashah, the second eldest sister, arrives home, full of good humor and laughter, saying that she has purchased flowers for trimming her hat. When Fania arrives and discovers Mashah spent ten cents on the flowers, she throws her own hat to the floor, kicking it in frustration. The whole family is furious at Mashah's frivolous waste of money. But the pretty Mashah is determined to rise above the poverty-stricken lifestyle of new immigrants,

Everywhere Mashah went men followed her with melting looks. And these melting looks in men's eyes were like something to eat and something to drink to her... The pride in her beautiful face, in her golden hair, lifted her head like a diamond crown. (Yezierska [16], 4)

The exaggeration embedded in metaphor and simile is highly entertaining. The tone of a book is always decided on its opening pages. The comic discrepancy between the fun-loving narrative and the reality of grim slum life of recent immigrants is meant for something, although it is a bit too early to pin that something down.

Sara's mother, Shenah, is worrying that "the landlady is tearing me my flesh, hollering for the rent" (ibid. 7) and complains to her father that "you're so busy working for Heaven that I have to suffer here such bitter hell" (ibid. 10) he tells the story of a woman who wanted earthly things but discovered that acceptance of those things meant she would be without all the rewards of Heaven. At this moment, all the four girls turn to their father: "Eyes widened, necks stretched, ears strained not to miss a word" (ibid. 11). The alliteration of "heaven" and "hell" and parallelism are both rhetorical devices employed to the effect of exaggeration and to the entertainment of the reader. Father, of course, succeeds in persuading the whole family to trust everything to the holy Torah. Mother promises that she will "be happy and thankful to live in poverty, as long as I know that our reward will be complete in Heaven" (ibid. 12). The comic discrepancy between the light-hearted narrative and the grim reality of ghetto life of recent immigrants is meant to brighten up with 
humor and optimism its dark side.

Sara's Father, Reb, is praying in the dining room when the collector from the landlord appears in the doorway demanding the rent. There ensues an argument and the woman "shut his book with such anger that it fell at his feet" (ibid. 18). Indignant at her insult of his holy book, Reb Smolinsky slaps her and is arrested. While Reb is in jail, Muhmenkeh, a kindhearted neighbor leaves two quarters for the family. Mashah takes one to buy the family's dinner and Sara takes the other. She "yelled like a fire engine" (ibid. 20) and makes a deal with Muhmenkeh to buy twenty-five herring at a penny each, takes them to "the corner of the most crowded part of Hester Street" (ibid. 21) and sells them all at two cents each. "My voice was like dynamite. Louder than all the pushcart peddlers, louder than all the hollering noises of bargaining and selling, I cried out my herring with all the burning fire of my ten old years" (ibid. 21). The profit of twenty-five cents makes her feel "richer than Rockefeller" (ibid. 22).

It began singing in my heart, the music of the whole Hester Street...all that was only hollering noise before melted over me like a new beautiful song.

It began dancing before my eyes, the twenty-five herring that earned me my twenty-five cents... it began dancing under my feet...I danced into our kitchen. And throw the fifty pennies like a shower of gold into my mother's lap. (ibid. 22-23)

Chapter I, Hester Street, concludes with the above scene filled with metaphor, simile, and analogy in a cheerful note, literally and metaphorically ending the mood of desperation in the household of the Smolinskys that looms large at the opening scene of the chapter. Sara is aptly nicknamed crazy-head. The trickster in her finds expression not only in the boundary-breaking action that earns her the profit of twenty-five cents but also in the creative narrative style.

Reb Smolinsky's language style becomes a target of Sara's narrative satire, too. He has strict rules and ideas about women and their role. Sara sums up her father's teaching from the Torah that women cannot hope to study the Torah or to make it into Heaven on their own and that they should attach themselves to a holy man and maybe a woman can slip in on her husband's good word so that she can serve him in Heaven.

A devoted preacher, Reb Smolinsky always has "the Holy Torah" on his lips. In his teaching and preaching of sexist religious doctrines, he constantly resorts to repetition, one rhetorical device that turns Father into a comically mechanical speaker.

When the whole family is starving, Father is optimistic and teaches, "What is there to worry about, as long as we have enough to keep the breath in our bodies? But the real food is God's Holy Torah" (emphasis added, ibid. 11). Although Mother requests Father to be more considerate about their family before he gives away a chunk of their hard-earned income to the charity, Father is not persuaded and instead reproaches Mother: "Woman! Stop my charities!
It's like stopping the breath of God in me. It says in the Holy Torah, "No man is too poor to help those that are poorer than himself." (Emphasis added, ibid. 90). Even when Mother becomes furious because messes up the grocery store, a purchase that has cost them 500 dollars, he finds a self-righteous excuse: "Woman! How do you suppose Rockefeller, or Morgan, or any of those millionaires made their start in America? They all began with empty hands" (ibid. 133). This metonymy sounds as if Reb Smolinsky had already become fully acculturated for two reasons, one, he is becoming practical because he aspires to become a businessman; two, the two millionaires represent the current trend of American culture and it has exercised some impact on him. This lack in him of the sound judgment of a businessman, however, betrays him that, in essence, Reb Smolinsky remains essentially a preacher of Judaism mired in the Old World.

Later, when Sara is growing up and becomes determined to pursue independence before marriage, Father grumbles: "No wonder it says in the Torah, 'Woe to a man who has females for his offspring" (Emphasis added, ibid. 205). "It says in the Torah, breed and multiply. A woman's highest happiness is to be a man's wife, the mother of a man's children" (Emphasis added, ibid. 206).

The list can be much longer where Reb Smolinsky speaks like an automaton, repeating excessively "Woman" and "the Holy Torah." Every time when he reproaches his wife and daughters with contempt and defends himself with teachings from "the Holy Torah", he repeats himself. What's more, his sentence pattern is assertive and rigid, which allows no room for negotiation. In Father's language, the mechanical repetitions report more facts apart from his limited vocabulary in Yiddish English. They not only ironically reflect Father's obstinate bias against the female members, the bread givers in his family, but also confirm his ludicrous confidence in his position as a patriarch in the Old World. Here is indeed the elementary American humorous situation with "the humor arising out of the gap between the cultural ideal and the everyday fact" (Rubin [12], 262), the ideal-Father's belief in the religion and its sexism — shown to be pompous and hollow, while the everyday life in America crude and funny. Although Father is living in modern America, his mechanical diction reflects his resistance to the new circumstances. He holds on to the impertinent values he has brought from the Old World and refuses to be immersed in the new life.

The third issue to be discussed in relation to Sara's narrative tricksterism is the carnival ceremony that the Jewish community has created in the wake of Father's victorious trial. When Father is arrested and taken away by the police, people of the neighborhood raise money to hire a lawyer for him, and the attorney shows Reb's Torah, which has a footprint on it. He says Father's slap in the face of his landlord's rent collection agent was the reaction to having the Jewish Bible degraded. The judge dismisses the case, claiming innocence for Father. For weeks, the whole block is plunged into a carnival: everyone is talking about the case 
because they are happy that a poor tenant has won in a legal battle against the landlord. According to Sara's observation, "It was like a holiday all the block when they had Father's trial (Yezierska [16], 24).

[t]he crowd got so excited, yelling and shouting with gladness, they almost carried Father home over their heads. (ibid. 25)

All the people stamped their feet and clapped their hands, with pleasure of getting even, once in their lives, with someone over them that was always stepping on them. (ibid. 26)

America is a country best known for people's love of litigations. The comic disparity between the hilarity of the Jewish community and our expectation results in the more humor in our perception.

In Rabelais and His World, Bakhtin [1] outlines the tension of modern consciousness, that is, the modern conflict between the individual and society. He writes about the rebellious stance of Renaissance authors who sourced their inspiration in popular culture and the carnivalesque spirit of folk humor. According to Bakhtin [1], the carnival moments of anarchy are "sharply distinct from the serious official, ecclesiastical, feudal, and political cult forms and ceremonials..., they built a second world and a second life outside officialdom, a world in which all medieval people participated more or less, in which they lived during a given of the year" (5-6). The carnivalesque trial under discussion epitomizes the essential ingredients in Bakhtin's definition of folk carnival. The most immediate compensation for the community locked in the ghetto is the holiday-like cerebration of the victory of the trial. People only seek liminal breakthrough without challenging the system of the social and economic circumstances. The opportunities are minimal for the immigrants to transform the poverty-stricken circumstances overnight. Yet, through the rituals of crowning (the victorious Father) and decrowning (the collection agent, representative of capitalism), two natural ingredients of a carnival, the holiday atmosphere of celebration offers them a liminal distance, which effectively suspends, for the time being, the reality of racist capitalism.

The Jewish humor demonstrated at the tricksterlike narrative of Bread Givers differs from the Jewish humor we encounter in novels by male Jewish writers like Portnoy's Complaint (Philip Roth, 1969), where a Jewish father is overwhelmed by a stereotype domineering mother. But the common ground still persists, that is, humor serves both as a defense mechanism against tragedy in hostile reality and as a cohesive agent that unites and strengthens a community, be it a family or a block of ethnic residence.

The exaggeration in Sara's narrative reveals her satiric attitude toward her father's sexist overtone in the religious doctrines about women's status. Therefore, Jewish humor can also be "an attack on those holding positions of authority within the community itself" (Zif [17], 56), although Father is the speaking mouth of the Jewish community, their religious authority.
On the basis of the above analysis, the trickster narrative of Chapter I have accomplished two functions, which are well summed up in the understanding of the nature of Jewish humor in "Jewish Humor in the United States" by Avner Ziv [17], a Jewish scholar:

One: a desire to distort the tragic reality, to alter it and make it laughable (and thus-less frightening and threatening). Here lie the elements of absurd humor, which fulfills the intellectual function of humor. One also finds here the elements of gallows humor which functions as a defense mechanism and is known by the term "laughter through tears." Two: the desire to preserve internal cohesiveness, to perceive what is special about "us" in contrast to what characterizes "them." (56)

The rebellion in Sara's narrative, shrouded in tricksterism, has two functions; it can both hurt and bond. First, it manages to achieve its main goal- to rattle the cage of the grim reality of being imprisoned in the ghetto and to shake the capitalist system epitomized in racism-even if not to bring it down. Sara's tricksterlike narrative serves the Jewish immigrant community as a defense mechanism and their union in the carnivalesque trial enables them to rise above the desperation and gain renewal for the time being. Tricksterism is humor in essence. According to Freud's "Humor,"

Humor has in it a liberating element... It refuses to be hurt by the arrows of reality or to be compelled to suffer. It insists that it is impervious to the woulds dealt by the outside world, in fact, that these are merely occasions for affording ti pleasure... Humor is rebellious. It signifies the triumph not only of ego, but also of the pleasure-principle, which is strong enough to assert itself here in the face of the adverse real circumstances. (qtd. in Morreall [11], 113)

Such a decisive, optimistic tone will prevail over the whole novel, rendering its reading a journey of laughter through tears. Such a feat is achieved by arranging a trickster narrator and protagonist in Sara. "With masks, laughter, and freedom from social laws and inhibitions, tricksters incarnate the carnivalesque" (Smith [13], 12). The victorious trial of Reb Smolinsky and the carnival in its wake are a good case in point where "trickster aesthetic envisions the trickster not only as an actual figure in the novel but also as a linguistic and stylistic principle" (Smith [13], 14).

\section{Humorous Characterization of Reb Smolinsky}

To see to it that we paint a comprehensive portrait of Reb Smolinsky, we need to keep well informed of his breeding as a scholar. But, first of all, a quote is in place from Freud's "Humor" for the definition of humorous characterization.

There are two ways in which the process at work in humor may take place. Either one person may 
himself adopt a humorous attitude, while a second person acts as spectator, and derives enjoyment from the attitude of the first; or there may be two people concerned, one of whom does not himself take any active share in producing the humorous effect, but is regarded by the other in a humorous light. (qtd. in Morreall [11], 112)

Every type of humor in Bread Givers is filtered through the lens of Sara's narrative. The humorous characterization of Reb Smolinsky is no exception. That is, he "does not himself take any active share in producing the humorous effect, but is regarded by the other (Sara in this case) in a humorous light." We are now ready to explore further how Father is humorously characterized first as a matchmaker for all his elder daughters and then as a businessman.

Sara's mother, Shenah, recalls that she was quite wealthy and more beautiful than Mashah in Russia as a girl and had her choice of suitors. Shenah's father wanted her to marry an educated man and Sara's father fitted that description. Shenah says that her husband knew nothing of business and sold things "for less than they cost" (Yezierska [16], 34), soon losing the family fortune that they had inherited from her father. To run away from poverty and war in Russia, they came to America "where Father thought things cost nothing at all" (ibid. 34) and "where milk and honey flows free in the streets" (ibid. 9). Shenah spends time recalling her youth and Sara says that the dingy apartment they live in melts away with the stories. Though Shenah says that her husband was a poor businessman and that he spent his time singing - as Solomon sang - rather than handling their business affairs, she nags at him about money but then compromises to his insistence that there are other things more important- the study of "the Holy Torah", for example.

It becomes common knowledge in Chapter I of the novel that Reb Smolinsky has retained his scholarly talents and his religious devotion to the Torah, always selling its sexist doctrines which require that, in order to gain access to Heaven, his wife and daughters must be bread givers in support of his religious study. In this regard, Reb Smolinsky seems to be consistent from past to present, be it out of religious bias or part of his character.

\subsection{Humorous Characterization of Father as a Matchmaker}

Having spent his entire life studying the Torah and other holy books of Judaism, Reb Smolinsky shuts himself in his own private world of religious study, a world that oceans apart from the real one where he and his family have to scratch for a living. A seasoned scholar of Judaism, Reb Smolinsky is entrenched in his world of religious fantasy, incapable of learning from his mistakes. The humorous characterization is uniquely epitomized in the following two areas.

First, Reb Smolinsky, a scholar of Judaism that teaches and preaches for life, never learns from mistakes, a comic incongruity illustrated by his interferences with his three elder daughters' marriages. Second, a scholar of Judaism devoted to the grace of "the Holy Torah", Reb Smolinsky turns out to be a staunch materialist.

The greatest danger to those around him is the fact that in his religious world, Reb proves to be exceptionally knowledgeable, thus drawing excessive respect from his community, a point proved in the victory of the trial and the carnival in its wake. Mashah, the most beautiful of his daughters, becomes a victim of Father's wrong judgment. At the beginning, Reb Smolinsky declares: "Poverty is an ornament on a good Jew, like a red ribbon on a white horse" (ibid. 71). Only moments later, when he spots and prefers a rich man as his future son-in-law, he exclaims: "A diamond-dealer! What more can you ask! The riches shine from him. The minute I saw him by the matchmaker, I said: This is the man I want for my daughter. You can see for yourself this man is a person of the world, and not a pale, half-starved poet" (ibid. 75). The incongruity in father's personality and philosophy is obvious and abrupt, catching both Mashah and the reader off guard. After all, Reb Smolinsky has been such a staunch preacher of "the Holy Torah" and thrift in material life, always proud of his scholarship, "I give my daughters brains enough to marry when their time comes, without the worries of a dowry" (ibid. 13). Yet, as father, without any warning, he simply changes his mind to worship money at the expanse of the scholarly gifts of a poet when the latter becomes his daughter's lover. Thus a very comic characteristic in Reb Smolinsky is revealed with this inconsistency between his religious belief and life philosophy, that is, he preaches one thing, but practices another. He even goes to the extreme with the assertion: "With this diamond-dealer in the family, all our troubles are over. You'll see he'll cover Mashah with diamonds. All through her riches, all of us will get rich quick " (ibid. 77). But Father's choice of Moe Mirsky for Mashah turns out to be a wrong judgment: the latter is only a vanity-stricken salesman in a jewelry store.

Then comes the opportunity for Father to interfere with Fania's marriage. The cloaks-and-suits manufacturer from the West has only one month's time in New York. So he has to quicken his love for Fania with many presents till all the girls on the block are green with envy. The heartbroken Fania, once deprived of her love for the poet, her first lover, doesn't care whether the fiance is "a rag-picker, a bootblack, I'd rush into his arms, only to get away from our house" (ibid. 80 ).

These two matches draw envy from neighbors: "We must dry our heads worry for bread, while they bathe themselves in milk and soak themselves in honey!". (ibid. 81) In Father's complacent imagination, the whole block becomes green with envy for his having one son-in-law being a diamond-dealer and another cloaks-and-suits manufacturer. He takes great pride in his contribution: "It was I, my brains, my knowledge of the world that brought them such golden 
luck marriages - and saw their gratitude" (ibid. 82).

It is true that, to some extent, marriage becomes the most transformative means that has helped change all of Sara's sisters from living in the ghetto to middle-class people settling down in suburbs. All these seem to have been initiated and secured by Reb Smolinsky's life philosophy, which is full of comic discrepancy: on the one hand, he is stuck in his world of Judaist scholarship; on the other, he turns out to be the most materialistic/capitalistic person in the Smolinskys. And the greatest irony lies in the fact that, Mashah and Fania and their families, though leaving the ghetto and settling down in suburbs, are unable to make both ends meet because Mashah has married a swindler while Fania a gambler.

Given the fact that he is never the breadwinner for his family, Father has a very different prescription for his sons-in-law. Actually his only precondition for them to marry his daughters is that they should be wealthy. When reality turns against him, that is, when both Mashah's and Fania's marriages suffer because of his wrong choices, he has no intention to offer apology, let alone shouldering any responsibility. "As you made your bed, so you got to sleep on it" (ibid. 85), this is Father's criticism of Mashah when the latter pays the first visit to her parents after her marriage. And Sara's narrative becomes highly racy and humorous: "But this time his preaching was in a whispering voice, because no matter how the shoe pinched us, we had to hide our shame from the neighbors" (ibid. 84).

Bertrand Russell said in his essay "How To Grow Old:" "mistakes are an essential part of education." Father is never able to learn from his mistakes. According to Henri Bergson's Laughter, anyone who behaves in a mechanic way is a comic character: we tend to handle our experience in a rigid, repetitious way, much as a machine might, treating what are actually new things and events as repetition of familiar concepts. And this is where laughter is useful, for it is a social gesture of mockery toward those who are not behaving in a flexible, context-sensitive way. The ridiculous, according to Bergson [3], is "something mechanical encrusted on the living" (18) and "something mechanical in something living" (38). Reb Smolinsky is not only incongruous in his conflicting criteria for the two sons-in-law, but also incongruous in his loud complacency with which he chose the sons-in-law and in his quiet humility when facing the consequences of his mistaken judgments.

It may be a good idea to remember that Sara's pursuit of higher education and professional status is a sign of feminism (a branch of modernism) rather than a struggle to make an adequate living. Sara's decision to defy her father occurs after the Smolinsky family store is established, and her decision to earn her own living occurs after Goldstein's offer of instant riches. For Sara, it is mobility itself that allows her to see the differences between acquiring wealth and social position through men and obtaining that wealth and position on her own.

Independence is so irresistible that Sara is willing to risk both security and comfort to start from scratch, economically speaking.

\subsection{Humorous Characterization of Father as a Businessman}

Father's materialism is portrayed in a tricksterlike manner through two events: one is his successful matchmaking effort for Bessie, the eldest daughter, and the other is his failure in the attempt to become a businessman through purchasing a store.

In Book I, the marriages of Sara's sisters are outlined not simply to explain why Sara is so motivated toward independence but to blame the sisters on the damage done to them, ultimately redistributing reproach from Reb Smolinsky to his elder daughters.

Bessie, the oldest of the sisters, resists Zalmon as a lover and resists Father for conceiving the marriage. She is meanwhile unable to resist taking care of Zalmon's youngest child, Benny. Yet, Bessie, whose fate is the product of a historical irony - she was probably raised in Europe - seems to deserve our pity, not our anger: "When the wedding came, she went quietly from our house to Zalmon's - the burden bearer had changed her burden" (Yezierska [16], 110). Bessie, like Mrs. Smolinsky, her mother is stuck in Hester Street, completely stripped of economic mobility.

On the other hand, he turns out to be the most materialistic member of the Smolinskys! His is matchmaker for all his daughters except Sara! His matchmaking is highly capitalistic, too. When it comes to Bessie's choice of husband, Father has no intention of changing his materialist spots.

Here is a humorous scene which records the change of attitude in Reb Smolinsky in Sara's narrative towards Mr. Zalmon, the widowed elder who elects to seek the most industrious Smolinsky daughter, Bessie, as his new wife right after his spouse dies.

When Zalmon, with his desire for Bessie, first approaches Reb, who has now become a matchmaker aiming for the US\$500 that Zalmon agrees to pay as the commission fee for his matchmaking effort, Sara's description of the fish peddler hardly hides her disgust:

His black greasy beard was spotted with scales from the fish. He had a big wart on his nose and his thick red lip was cracked open in the middle. It smelled from him yards away, the fish he was selling. And he breathed thickly from stuffing himself with too much eating. (ibid. 91-92)

Later, when Zalmon returns to the Smolinsky home, dressed in an excessively gentlemanly and somewhat opulent manner, his naturally repulsive body is transcended by the transformative power of his wealth. The tone of narration is distinctly different and satiric:

$[T]$ he door opened and a smell of perfume filled our kitchen. A man entered. He held in his hand a big box tied with red ribbon. He wore a new black suit and looked just like those wax figures in the show window where they have clothes to hire for weddings. Above the white starched collar was a young, clean-shaved face. Only by the thickness of 
his bushy eyebrows, and the wart on his nose, did we begin to recognize that this new shaved-man was Zalmon, the old fish peddler, without his beard. (ibid. 99)

Father's materialism/capitalism is humorously struck home. Bessie, nick-named "Burden Bearer," becomes a burden bearer in her new household.

Father uses the money he earns from Zalmon to start a business. He buys a grocery store for an unbelievably low price. Father immerses himself in the pride of getting a real bargain. But soon they find out that it is a fraudulent deal, with beautiful boxes containing no goods inside them. Father, of course, never feels guilty of spending all the money buying nothing. Instead, he comforts himself and Mother:

Maybe God let me off with the mere loss of money to spare me a worse misfortune.... If only you had a little understanding of life, you would thank God for His mercy on us.... This man who robbed me only pushed me closer into the arms of God. Now I know that everything happens to us is from God, for our good...Money lost, nothing lost. Hope lost, all is lost. The less money I have, the more I live on hope. (ibid. 125)

The caricature of Father again exposes the discrepancy between reality and ideality. He announces, eager to prove the value of his idealized self in the capitalist world: "In America, there is no need to be poor, if you only got brains and money to begin something" (ibid. 115), and he continues: "Other people have made fortunes in America. Why shouldn't I? it's only fools who remain poor" (Ibid.) Reality is cruel, however. This event also illustrates the dangers of modernity. Berman [4] describes the modern experience as "a unity of disunity":

[Modernity] destroys everything we have, everything we know, and everything we are... It pours us all into a maelstrom of perpetual disintegration and renewal, of struggle and contradiction, of ambiguity and anguish. (15).

Father's mindset and failure mirror his dislocation in the New World of modernity, stirring up our pathos for a ludicrous and pathetic figure in him.

\section{Conclusions}

Northrop Frye pointed out that humor has regenerative effect. Sociological, linguistic, and literary articles that have treated humor in tricksterism are often more concerned with its structure or its social significance than with examining the pleasure it creates. This paper makes a point of balancing itself between the pleasure humors in tricksterism itself creates and its social significance.

Berman [4] offers an evocative portrayal of the modern experience in All That Is Solid Melts into Air:

Modern environments and experiences cut across all boundaries of geography and ethnicity, of class and nationality...it pours us all into a maelstrom of perpetual disintegration and renewal, of struggle and contradiction, of ambiguity and anguish. To be modern is to be part of a universe in which, as Marx said, "all that is solid melts into air." (13)

These paradoxical experiences of modernity resonate with the immigrant experiences of the Smolinskys in Bread Givers that have been treated with tricksterism. To survive the ravages wrought by modernity, as Frosh [7] contends, individuals have to "assert their own creativity" and "find a way of living with continually dissolving realities and fluctuating boundaries" (6). The Smolinskys are expected to adapt to the new circumstances with a modern "make-it-new" attitude. Tricksterism is part of this tool kit. The humor in it can both hurt and bond. It has multiple functions, first as the corrective for the mechanical inelasticity in the family, particularly in Reb Smolinsky, then as the therapy that helps balm the wounds of capitalism and racism; finally as a cohesive that bonds the family and the Jewish community by extension.

We witness how the novel's narrative voice naturally develops over the course of the novel from a hybrid Yiddish-English language to a more aestheticized Standard American English grammar that reflects the acculturation, more than mere linguistic assimilation of Sara the protagonist, a development to be expected in a Bildungsroman.

With her unique prose, Yezierska develops a sophisticated modernist aesthetics that reveals the public role of tricksterism and its ability to criticize and transform the social sphere. Her creative literary humor, with its exaggerated use of broken immigrant English and Yiddish, is designed to challenge a then national consensus on successful linguistic assimilation.

In Book I, it is obvious that only Father and Mother backtrack sometimes and employ some Yiddish words. Sara proves to be the person using Yiddish the least of the Smolinskys. Chapter $\mathrm{X}$ is the first chapter of Book II, "Between Two Worlds," where Sara embarks on her pursuit for independence at economical, emotional, and intellectual levels. Aptly, Chapter X has a title, "Shut the Door." This chapter serves as Sara's clear division between the ghetto of Hester Street and the outside world of freedom, where she will realize her American dream. And her first step is to have a room of her own, Virginia Woolf's prescription for female independence. When she shuts the door of the first room she has rent, however shabby it is, she has initiated herself into the adult world, economically and spiritually. In her initial imagination for independence, she dreams of becoming a schoolteacher, with a class of schoolchildren looking up at her: "It was like looking up to the top of the highest skyscraper while down in the gutter" (Yezierska [16], 155). At this point, Sara shows her progress in acculturation not only through her precise English but also through her acculturated simile: the turn-of-the-century America is experiencing modernization best in its skyscrapers in 
Chicago and New York City. Book II concludes with the facts that Sara has risen from a sweatshop girl to a nights-school student and ultimately to a college graduate, winning the college's writing contest. Book III deals with Sara's life in the New World.

Bread Givers narrates the bitter rebellion of young Sara Smolinsky against her tyrannical father, a failed Hebrew teacher who symbolizes the Old World. After flirting briefly with the prospect of marrying a wealthy man, Sara accepts being ostracized and works her way through night school and college to become a schoolteacher.

Sara agrees at the novel's end to marry the principal of her East Side grammar school, also a Jew. Sara then is inspired to ask her father, now widowed, to move into their future home. Such an ending does not mean that "Sara's hard-won rapprochement between culture and opportunity as a pyrrhic victory" (Ferraro [8], 388). Such an ending is a credit to ethnic modernism, which can have an option different from the so-called mainstream modernism, that is, the former can assert its independence in choosing to maintain links between modernity and tradition. After all, modernity, which "threatens to destroy everything we have, everything we know and everything we are" (Berman [4], 15), also promises, alongside tricksterism, "adventure, power, joy, and growth" (Ibid. 15).

\section{REFERENCES}

[1] Mikhail Bakhtin. Rabelais and His World. Bloomington, IN: Indiana University Press, 1984.

[2] Helena Bassil-Morozow. The Trickster in Contemporary Film. London and New York: Routledge, 2012.

[3] Henri Bergson. Laughter, an Essay on the Meaning of the Comic. Trans. Cloudesley Brereton and Fred Rothwell. Mineola, New York: Dover Publications, Inc., 2005.
[4] Marshall Berman. All That Is Solid Melts into Air, The Experience of Modernity. London: Verso, 1983.

[5] Kimberly A. Christen. Clowns \& Tricksters, An Encyclopedia of Tradition and Culture. Denver, Colorado: ABC-CLIO, 1998.

[6] Ralph Ellison. Shadow and Act. New York: Random House, 1964.

[7] Thomas J. Ferraro. Ethnic Passages, Literary Immigrants in $20^{\text {th }}$-Century America. Chicago: University of Chicago Press, 1993.

[8] Thomas J. Ferraro. "Ethnicity and the Marketplace" in The Columbia History of the American Novel, Emory Elliott (ed.). New York: Columbia University Press, 2005. 380-406.

[9] Stephen Frosh. Identity Crisis: Modernity, Psychoanalysis and the Self. London: Macmillan Education, Ltd., 1991.

[10] Henry Louis Gates, Jr. The Signifying Monkey. New York: The Oxford University Press. 1988.

[11] John Morreall (ed.). The Philosophy of Laughter and Humor. New York: SUNY, 1987.

[12] Louis D. Rubin, Jr. "The Great American Joke." The Comic Imagination in American Literature, Louis D. Rubin (ed.). New Brunswick, N.J.: Rutgers University Press, 1973. 3-15.

[13] Jeanne Rosier Smith. Writing Tricksters: Mythic Gambols in American Ethnic Literature. Berkeley: University of California Press, 1997.

[14] Victor Turner. "Myth and Symbol." The International Encyclopedia of Social Sciences. New York: Macmillan, 1968. 576-582.

[15] Gerald Vizenor. The People Named the Chippewa. Minneapolis: University of Minnesota Press, 1984.

[16] Anzia Yezierska. Bread Givers. New York: Persea Books, 1975.

[17] Avner Ziv (ed.). "Jewish Humor in the United States" in Jewish Humor. New Brunswick: Transaction Publishers, 1998. 56-63.

\footnotetext{
${ }^{i}$ Anzia Yezierska has been a phenomenal success since Alice Kessler Harris "rediscovered" this Jewish woman writer in 1975. Yezierska has been studied from the perspectives of modernism, feminism, ethnic study, etc. It seems nobody has yet noticed tricksterism in this highly productive writer. This paper attempts to explore two parts of tricksterism in the novel, first, the narrator protagonist Sara's trickster narrative and then the humorous characterization of Reb Smolinsky, her father.
} 